\title{
LEGELTETÉSSEL A KLÍMÁÉRT
}

\section{GRAZING FOR CLIMATE}

\author{
Koncz Péter projektmenedzser, pkoncz@gmail.com, \\ Pintér Krisztina ${ }^{2}$ egyetemi docens \\ Balogh János ${ }^{2}$ egyetemi docens \\ Papp Marianna² doktorandusz \\ Hidy Dóra ${ }^{3}$ modellfejlesztő \\ Nagy Zoltán² egyetemi tanár \\ 'Duna-Ipoly Nemzeti Park Igazgatóság, Budapest \\ ${ }^{2}$ Szent István Egyetem Növénytani és Ökofiziológiai Intézet, Gödöllő \\ ${ }^{3}$ MTA Agrártudományi Kutatóközpont, Martonvásár
}

\begin{abstract}
ÖSSZEFOGLALÁS
Napjainkban élénk vita folyik arról, hogy az állattenyésztés és ezen belül a legeltetés milyen mértékben járul hozzá a klímaváltozáshoz. Mérések, adatok és modellek mellett eszmék és érdekek sorakoznak egyik vagy másik technológia, illetve érvrendszer mellett vagy ellen. Globális szinten látható, hogy a klímaváltozás következtében csökken az állateltartó gyepek produktivitása és ezzel párhuzamosan a húsalapú élelmiszer-ellátás biztonsága. Az állattenyésztés azonban nemcsak elszenvedője, illetve részbeni okozója a klímaváltozásnak, hanem a megoldás része is. Számos olyan technológia létezik, amely a klímaváltozáshoz történő adaptáció mellett a mitigációt is szolgálja. Hazai kutatásaink során például azt találtuk, hogy az extenzív legeltetésre alapozott állattenyésztés, kedvező csapadékellátottság mellett lehet klímabarát. Azt tapasztaltuk, hogy az üvegházhatású gázok kibocsátását (a legelő, kaszáló és a téli szállás szintjén) a legelő növényzetének szén-dioxid-felvevő kapacitása képes volt ellensúlyozni. Az ilyen és ehhez hasonló kutatások szintetizálását több nemzetközi szervezet, illetve projekt keretében végezzük el. Ezek során nemcsak újabb kutatási témákat javaslunk, hanem a gazdálkodók, döntéshozók és a fogyasztók számára tájékozódási alapot szolgáltatunk. Az Európai Innovációs Partnerség-AGRI "Legeltetéssel a szénmegkötésért" fókuszcsoportjában például többek közt azt vizsgáltuk, hogy a különböző legeltetési technológiák, illetve kifizetési mechanizmusok hogyan ösztönzik a szénmegkötést. Ilyen kifizetési mechanizmus a Portugal Carbon Fund, amely bizonyítottan szénmegkötő technológiák alkalmazása esetén nyújt juttatást a gazdálkodóknak.
\end{abstract}

\section{ABSTRACT}

The role of livestock and grazing in climate change is highly debated. Besides measurements, data and models there is a wide range of ideas and interests which supports or opposes one or the other livestock management technology. At global scale, due to climate change, the live- 
stock supporting capacity of grasslands have been declined, thus threatening meat-based food security. However, livestock is not only one of the causes of climate change, but it is also part of the solution in combating climate change. There are a large number of management technologies which could be applied in climate change mitigation and adaptation. Our results showed that extensive grazing management could be climate friendly, provided that there is enough precipitation. We observed that the total greenhouse gas emission of the grazed, mowed and feeding system was offsetted by the carbon-dioxide uptake of the vegetation of the grazed grassland. We synthesize these kinds of researches in various international organizations. During these processes we not only recommend further research topics but we also provide orientation for farmers, decision makers and consumers. For example, in the EIP-AGRI 'Grazing for Carbon' Focus Group we summarized how different grazing methods and incentives contribute to the carbon sequestration of grasslands. Such an incentive mechanism is the Portugal Carbon Fund, which provides financial support for farmers, provided that there is net carbon sequestration on their grazed grasslands.

Kulcsszavak: állattenyésztés, klímaváltozás, mitigációs technológiák, extenzív legeltetés, széndioxid-kvóta

Keywords: livestock, climate change, mitigation technologies, extensive grazing, carbon credit

\section{AZ ÁLLATTENYÉSZTÉS ÉS A KLÍMAVÁLTOZÁS VISZONYA}

Az állattenyésztés nemcsak jelentős mennyiségủ üvegházhatású gáz kibocsátásával, de számottevő megkötő kapacitással is bír. Ez utóbbi mérsékli éghajlatunk megváltozását. Tény, hogy globálisan az állattenyésztés az üvegházhatású gázok kibocsátásának 14\%-áért felelős (Gerber et al., 2013). Ám ezt ellensúlyozva, az állateltartó gyepek a szén(-dioxid) megkötésük révén a kibocsátások 4\%-át lennének képesek semlegesíteni (Soussana-Lüscher, 2007). Az állattenyésztésben a szénmegkötö kapacitás növelése mellett számos olyan mitigációs technológia rejlik, amelyekkel csökkenthető az üvegházhatású gázok kibocsátása (Bellarby et al., 2013; Smith et al., 2008). A kibocsátások visszafogására a szektor hatékonyságának növelése érdekében is szükség van. Ugyanis az éghajlatváltozás következtében elsősorban a mediterrán, illetve a kontinentális klímán csökkenhet a gyepek és a gyepekre alapozott állattartás produktivitása. Csak egy példa: 2006 és 2011 között olyan mértékủ szárazság volt Szíriában, hogy a tenyésztett állatok 80\%-a elpusztult. A változó klíma, illetve a szárazság nem pusztán a gyepek produktivitására vagy például a biodiverzitására, de ezeken keresztül az élelmiszer-ellátás biztonságára is jelentős hatással van. Ezért lokális és globális léptékben, az üvegházhatású gázok kibocsátását csökkentő technológiák feltárása és alkalmazása mellett, az erre irányuló tevékenységek terjesztésére és támogatására is égetően szükség van. 


\section{GYEPEK SZÉNMEGKÖTÉSE}

Az EU különböző kutatási és innovációs programok keretében számos olyan folyamatot támogat, amelyek hozzájárulnak az állattenyésztés alkalmazkodó és mitigációs képességének növeléséhez, illetve a húsalapú élelmezés fenntartható fejlődéséhez. Így például az Európai Innovációs Partnerség (EIP) AGRI Legeltetéssel a szénmegkötésért fókuszcsoportjában, különböző legeltetési és tartástechnológiák mellett az ösztönző és támogató mechanizmusokat is górcső alá vettük. Tettük ezt annak érdekében, hogy átláthatóbb képet alkothassunk a legeltetésre alapozott állattenyésztés szénmegkötésben betöltött jelenlegi és jövőbeni lehetséges szerepéről.

A szintézis során többek között megállapítottuk, hogy akár a rotációs, akár a folyamatos legeltetés esetében a legeltetett gyepek éves szinten nettó szénmegkötők. Ugyanakkor például a kaszálás vagy a legeltetés felhagyása nettó kibocsátást (szénveszteséget) eredményezhet. Az ökoszisztéma-léptékü szén-dioxid-csere, illetve a szénfelvétel két jelentős és ellentétes irányú folyamat: az állatok, a növényzet és a talaj légzésének, illetve a növényzet fotoszintézisének, tehát a bruttó primer produkciónak az éves különbsége. Gyepek esetében szénmegkötésröl akkor beszélhetünk, ha a szén végső soron a talajban akkumulálódott (fás szárú vegetáció hiányában a szén raktára elsősorban a talaj). A nettó felvétel erősen függ az abiotikus paraméterektől, így például a megfelelö csapadékellátottságtól. Hazánkban legalább évi 500 mm csapadékra van szükség ahhoz, hogy a gyepökoszisztéma nettó több szenet kössön meg, mint amennyit kibocsát. A nettó felvétel továbbá erősen függ a besugárzás mennyiségétől, a hőösszegtől, a páratartalomtól, de a kezelések jellegétől és azok intenzitásától is. Ökoszisztéma-léptékü szén-dioxid-forgalmi vizsgálatok hazánkban csak Bugac, Szurdokpüspöki, illetve a Hegyhátsál mellett lévő gyepek esetében történtek (MTA - Szent István Egyetem Növényökológiai Kutatócsoport, Eötvös Loránd Tudományegyetem Meteorológiai Tanszék). A bugaci kutatásaink tapasztalatai alapján, a vizsgált szürkemarha-legelö szénfelvétele évente közel egy tonna volt hektáronként (2011-2013). A kaszáló ezzel szemben közel ugyanennyit bocsátott ki, a kaszálást követő jelentős ökoszisztéma-légzés és alacsony szénfelvétel miatt (Koncz et al., 2017). Az eltérő kezelések mellett a legeltetés intenzitása szintén jelentősen befolyásolja a szénfelvételt. Se az alul, se a túllegeltetés nem kedvez az éves nettó szénfelvételnek.

Az optimálisan beállított legelési intenzitás mellett ismert, hogy a gyepek szénmegkötése felülvetéssel, öntözéssel vagy éppen trágyázással tovább növelhető (Conant et al., 2017). Az arra alkalmas gyepek pillangósokkal történő felülvetése akár 600 kg-mal képes növelni évente és hektáronként a talaj széntartalmát (Conant et al., 2017). A pillangósok közé tartozó lóherefajokkal történő felülvetés nemcsak a talaj szén-, hanem nitrogéntartalmának növekedéséhez, illetve az álla- 
tok jobb tápanyagellátásához is hozzájárul. Sőt, a mélyen gyökerező lóherefajok a gyep szárazságrezisztenciáját is növelik. A gyepek pillangósokkal történő felülvetése tehát egy igazi win-win-win klímastabilizációs technológia. Fontos, hogy a talajok magas szervesszéntartalma nemcsak az üvegházhatású gázok mérlege, hanem a talaj víz- és tápanyag-gazdálkodásának szempontjából is kedvező. Az arra alkalmas helyeken az öntözés is hozzájárul a produkció, így a szénmegkötés növeléséhez, de sok helyen ez nem valósítható meg. Ezzel szemben a tájszintü vízgazdálkodás reálisabb megoldás, így például kisebb patakok visszaduzzasztásával a talajvízszint depressziója a vizes élőhelyeket övező gyepek esetében is csökkenthetö. (A Duna-Ipoly Nemzeti Park Igazgatóságnál éppen egy ilyen komplex élőhely-rekonstrukciót hajtunk végre a Hajta mentén.) Természetesen a vizes élőhelyeken jelentős a szerves anyagok bomlásából eredő metánkibocsátás, akárcsak a kérődzők fermentációs folyamatai során, de ez utóbbi kibocsátás az élelmiszer-ellátás velejárója. Tény, hogy egy közép-európai tartású tejhasznosítású marha évente $58 \mathrm{~kg}$ metánt bocsát ki, amely $2000 \mathrm{~kg}$ szén-dioxid-egyenérték kibocsátásnak felel meg. Ennyi szén-dioxidot egy $100 \mathrm{~km}$-en 8 liter üzemanyagot fogyasztó autó a Budapest és Peking közti táv megtétele alatt produkál. Ennek a szén-dioxidnak a lekötéséhez két és fél focipályányi természetközeli gyepre van szükség. A metanogenezis, tehát a kérődzés során termelt metán mennyiségének szabályozása, csökkentése a klímaváltozás mitigációjának szempontjából kézenfekvőnek tünik ugyan, de a folyamat sikeressége kétségbe vonható. A marhák antibiotikummal, halogénekkel, ionofórokkal történő kezelése átmenetileg csökkenti ugyan a kibocsátást, de egyrészt rezisztencia alakulhat ki a kezelésekkel szemben, másrészt ezen anyagok előállítása során is keletkeznek üvegházhatású gázok. Harmadrészt az ember megjelenése előtt a kérődzők metánkibocsátása jelentősebb volt, mint napjainkban. Ezért sem feltétlenül az állati eredetű metanogenezis csökkentése az elsődleges megoldás. (Ettől még tény, hogy a metánkibocsátás egy kurrens probléma, és ebből a szempontból lényegtelen, hogy mi volt a múltban.) A szénmérlegen túl mindazonáltal nélkülözhetetlen, hogy lehetőség szerint a farmok teljes üvegházhatású gáz mérlegét felmérjük, és ezen keresztül értékeljük és támogassuk a különböző gyep- és legelőgazdálkodási formákat.

\section{FARMSZINTŰ ÜVEGHÁZGÁZ-MÉRLEG}

A farmszintű üvegházhatású gázok mérlegében a szénfelvétel mellett a laterális szénfluxusok (például a farmról elvitt állatok, behozott takarmány), illetve a metán- és a dinitrogén-oxid-fluxusok játszanak fontos szerepet. A metán az állatok kérődzése mellett a trágya bomlása során kerül a légkörbe, míg a metanotróf baktériumoknak köszönhetően a talaj minimális mértékben, de a metán nyelője lehet. A légkörből kikerülő metán jelentősebb része nem bioló- 
giailag, hanem a légköri hidroxilgyökökkel való reakciója során semlegesítödik. A dinitrogén-oxid szintén a trágya bomlása, illetve a talaj denitrifikációs, nitrifikációs folyamatai során kerül a légkörbe. A dinitrogén-oxid lebomlása reduktázok, illetve a sztratoszférikus fotokémiai oxidáció révén ultraibolya fény hatására valósul meg. A különbözö fluxusok összegzéseként alkothatjuk meg a farmszintü üvegházgáz-mérleget.

Az ország első farmszintü üvegházgáz-mérlegének elkészítésekor azt találtuk, hogy az extenzív legeltetésre alapozott gazdálkodás lehet klímabarát, mert a farm (a legelő, kaszáló és a téli szállásból álló rendszer) üvegházgáz-mérlege, csapadékos évben nettó megkötő volt (1,3 t CO $\mathrm{CO}_{2}$-egyenérték ha $\left.{ }^{-1} \mathrm{é}^{-1}\right)$ (Koncz et al., 2017). Az 1. ábrán a farmszintü üvegházgáz-mérleg évenkénti alakulása látható. A legelő szén-dioxid-felvétele képes volt kompenzálni az állatok ( $\sim 00 \mathrm{db}$ szürkemarha), a trágya és a talaj szén-dioxid-egyenértékben kifejezett üvegházhatású gáz kibocsátását, illetve a kaszáló szén-dioxid-veszteségét is. Az ökoszisztéma-léptékủ szén-dioxid-forgalommérés folyamatos volt 2011 és 2013 között, az egymás mellett elhelyezkedő legelt és kaszált mintaterületen két mikrometeorológiai állomás segítségével. A laterális fluxusokat szintén napi bontásban követtük nyomon. A talaj metán- és dinitrogén-oxid-kibocsátását, illetve számos olyan háttérváltozót (levélfelületi index, biomassza, talajlégzés, cönológiai paraméterek), amely a fluxusok irányának és nagyságának értelmezésében segített 56 terepi nap során kampánymérésekkel követtük nyomon.

A farmot gondozó gépek (kaszáló, bálázó) vagy a farmot üzemeltető adminisztráció kibocsátása nem az ökoszisztéma-mérleghez tartozik, ezek a fluxusok más szektorban jelennek meg. Teljes életciklus-elemzésnél természetesen nélkü-

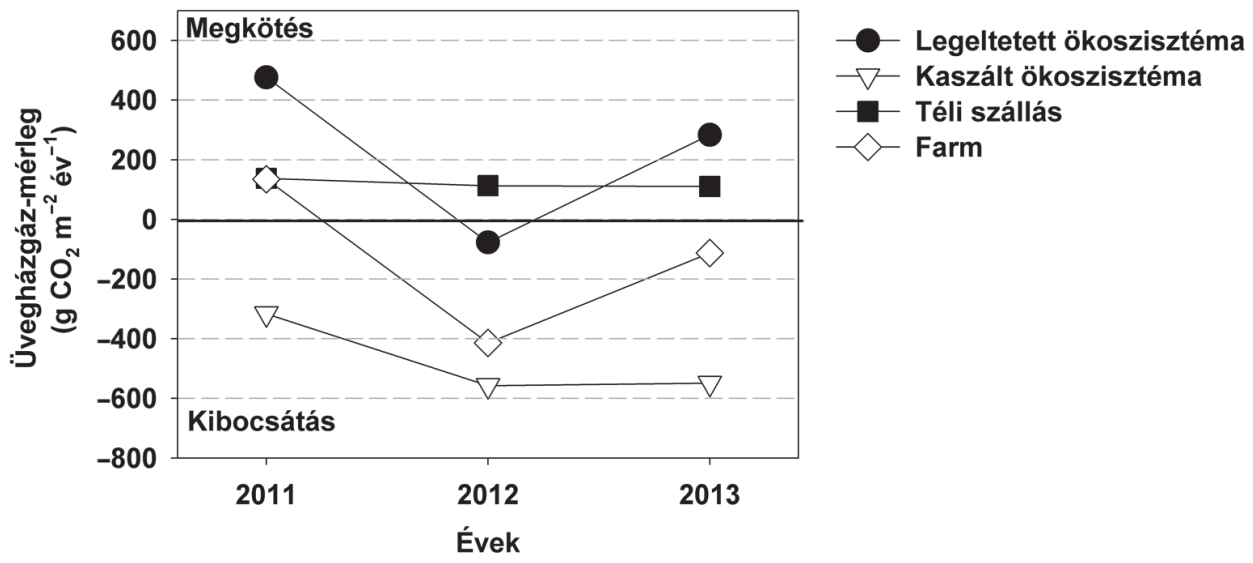

1. ábra. A farmszintű üvegházgáz-mérleg évenkénti változása 
lözhetetlen ezeknek a fluxusoknak a számszerüsítése is, bár meglepő, hogy például a gyepek jelentős szénmegkötésével vagy éppen kibocsátásával sok esetben a teljes életciklus-elemzésben nem is számolnak.

A fluxusok mérésére, illetve a mért rendszer határainak rögzítésére, egységesítésére szükség van, mert a különböző technológiák klímaváltozásban betöltött szerepe csak így, holisztikusan értelmezhetö. A mért fluxusok és a rendszerhatárok különbözősége, a kevés számú vizsgálat, és adott esetben a különböző érdekek mentén történő kutatások miatt jelenleg éles vita folyik arról, hogy a biovagy az intenzív gazdálkodásra, illetve a fü- vagy a gabonaalapú tartásra (grass vs grain-fed) alapozott hústermelés jár-e együtt fajlagosan alacsonyabb gázkibocsátással (Garnett et al., 2017)?! Végső soron a döntéshozók, illetve a lakosság kezében van a választás lehetősége, de nem egyszerủ a helyzet. Egy-egy termék vásárlása, illetve egy-egy agrártevékenység támogatása, ösztönzése nemcsak az egész termékláncra, de a gyepek szénmegkötésére, így klímánkra is kihat.

\section{KIT VAGY MIT TÁMOGASSUNK?}

Az üvegházhatású gázok kibocsátásának jelentős része az állattenyésztés szükséges velejárója. Az állattenyésztés a világon közel egymilliárd embernek ad munkát, köztük kétszázmilliónak éppen a világ legszegényebb régióiban (Rota-Sperandini, 2009). A legeltetésre alapozott állattartásnak számos helyen indokolt a növénytermesztéssel szembeni létjogosultsága. Például ott, ahol a növénytermesztés már nem gazdaságos, sőt a gyepek feltörése kifejezetten jelentős üvegházgáz-kibocsátással járna. Az extenzív legeltetésre alapozott állattenyésztés a gyepek genetikai, faji, habitat- és a kulturális diverzitásához is hozzájárul. Számos szolgáltatás fenntartásáért ugyanakkor nem jár kifizetés. Jelenleg az EU közös agrárpolitikájának részeként éppen azokat a sokrétủ szolgáltatásokat (klímastabilizálás, talajerő-védelem, tájképi diverzitás) „árazzák be", amelyek ezen agrárágazathoz köthetőek, de eddig még célzottan ezekért nem járt támogatás. Az intenzifikálás ugyan produkciónövekedést eredményez, de ez egyúttal az ökoszisztéma-szolgáltatások és a funkciók sérüléséhez, illetve a diverzitás csökkenéséhez vezet. Az EU agrárpolitikája az intenzifikálás híján kiesett jövedelmet pótolja agrártámogatások formájában. Ezek a kifizetések kompenzálják a gazdákat, hozzájárulva a közösség szempontjából fontos ökoszisztéma-szolgáltatások fenntartásához. Az agrártámogatások első pillére alatt bevezetett zöldesítés az állandó gyepek, ökológiai fókuszterületek fenntartásával indirekten hozzájárul a gyepek szénmegkötő kapacitásának megtartásához is. Ezentúl azonban léteznek olyan mechanizmusok is, amelyek direktebben járulnak hozzá a gyepek szénmegkötő kapacitásának növeléséhez, a produkció növelése mellett. 
A Portugesse Carbon Fund keretében például a szén-dioxid-kvóták kereskedelméből befolyó összegből finanszírozzák azokat a legelőgazdálkodási tevékenységeket, amelyek bizonyítottan hozzájárulnak a nettó szénmegkötés növeléséhez. A legelők pillangósokkal történő felülvetése során ebben a projektben így hektáronkét évente 5 tonna szén-dioxidot kötöttek meg. A programban tízezer farmer vett részt, közel 40 ezer hektáron végezték el a felülvetést, amely a portugál mezőgazdasági területek 4\%-át érintette. A gazdáknak a területalapú támogatás és a zöldesítés mellett ez többletkifizetést eredményezett. Egy másik példa az a FAO által kidolgozott program, amely a fejlődő országokban járulhat hozzá az üvegházhatású gázok kibocsátásának csökkentése mellett a produkció növeléséhez. A program a szén-dioxid-kvóta piacán keresztül a tejágazat kistermelői számára nyújt támogatást a fejlődő országokban, amennyiben bizonyítottan kibocsátáscsökkentö technológiákat alkalmaznak. Fontos, hogy a termelés volumene például energiabarát eszközök használatával növekedhet. Olyan mechanizmusokra van tehát szükség, amelyek a mitigáció mellett a termelékenységnövekedést is ösztönzik.

Sok minden vitatható: a támogatások létjogosultsága, a döntéshozók és a fogyasztók felelőssége, a mérések reprezentativitása stb. Egy azonban bizonyos: a talajok csendes szénakkumulációját sok szempontból érdemes fenntartani.

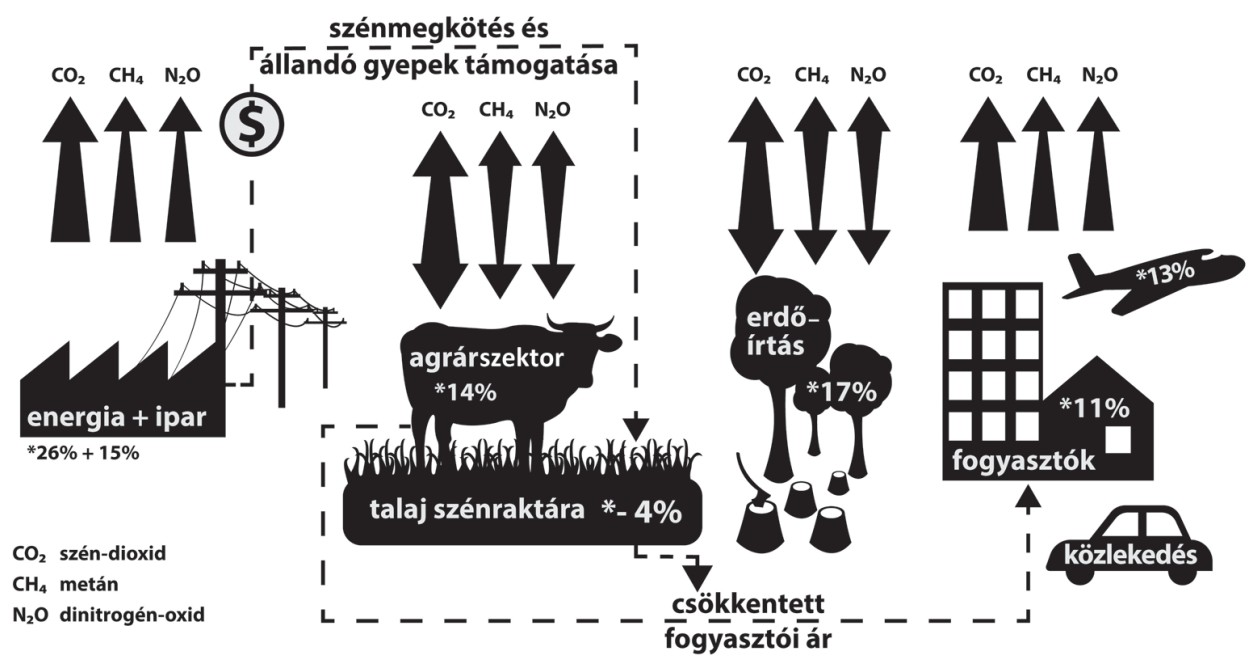

*Antropogén eredetü üvegházhatású gázkibocsátás szektoronként

2. ábra. Antropogén eredetű üvegházhatású gázok kibocsátása szektoronként. A szaggatott vonal illusztrálja azt a helyzetet, amikor az üvegházhatású gázok kibocsátói kibocsátásra jogosító kvótákat vesznek azoktól, akik az üvegházhatású gázok megkötésért felelnek.

A szénmegkötésért járó kifizetés, hasonlóan az állandó gyepek után járó támogatásokhoz, mérsékli a gyepekre alapozott állattartásból eredő termékek fogyasztói árát. 


\section{IRODALOM}

Bellarby, J. - Tirado, R. - Leip, A. et al. (2013): Livestock Greenhouse Gas Emissions and Mitigation Potential in Europe. Global Change Biology, 19, 3-18. DOI: 10.1111/j.1365-2486.2012.02786.x, https://www.researchgate.net/publication/236057216_Livestock_greenhouse_gas_emissions_ and_mitigation_potential_in_Europe

Conant et al. (2017): Grassland Management Impacts on Soil Carbon Stocks: A New Synthesis. Ecological Applications, 27, 2, 662-668. DOI: 10.1002/eap.1473, https:/esajournals.onlinelibrary.wiley.com/doi/full/10.1002/eap.1473

Garnett, T. - Godde, C. - Muller, A. et al. (2017): Grazed and Confused? Ruminating on Cattle, Grazing Systems, Methane, Nitrous Oxide, the Soil Carbon Sequestration Question - and What It All Means for Greenhouse Gas Emissions. FCRN-University of Oxford, https://www.fcrn. org.uk/sites/default/files/project-files/fcrn_gnc_report.pdf

Gerber, P. J. - Steinfeld, H. - Henderson, B. et al. (2013): Tackling Climate Change through Livestock: A Global Assessment of Emissions and Mitigation Opportunities. Rome: FAO, http:// www.fao.org/3/a-i3437e.pdf

Koncz P. - Pintér K. - Balogh J. et al. (2017): Extensive Grazing in Contrast to Mowing Is Climate Friendly Based on the Farm-Scale Greenhouse Gas Balance. Agriculture, Ecosystems and Environment, 240, 121-134. DOI: 10.1016/j.agee.2017.02.022, http://real.mtak.hu/49607/

Rota, A. - Sperandini, S. (2009): Livestock and Pastoralists. Livestock Thematic Papers: Tools for Project Design. Rome, Italy: International Fund for Agricultural Development (IFAD)

Smith, P. - Cai, Z. - Martino, D. et al. (2008): Greenhouse Gas Mitigation in Agriculture. Philosophical Transactions of the Royal Society of London. Series B, 363, 789-813. DOI: 10.1098/ rstb.2007.2184, https://royalsocietypublishing.org/doi/full/10.1098/rstb.2007.2184

Soussana, J. F. - Lüscher, A. (2007): Temperate Grasslands and Global Atmospheric Change: A Review. Grass and Forage Science, 62, 127-134. DOI: 10.1111/j.1365-2494.2007.00577.x, https:/www.researchgate.net/publication/227738505_Temperate_grasslands_and_global_atmospheric_change_A_review 